\title{
A critical history of 2012 mythology
}

\author{
John W. Hoopes \\ Department of Anthropology, University of Kansas, \\ 1415 Jayhawk Blvd., Lawrence, KS 66045, USA \\ email: hoopes@ku.edu
}

\begin{abstract}
The notion that December 21, 2012 will bring physical catastrophes, a transformation of consciousness, or even a New Age is an unanticipated and unintentional consequence of early speculation by credentialed academic experts. It has grown as a result of its subsequent interpretation through the lens of speculative, counterculture metaphysics by individuals with both academic and non-academic backgrounds. This article provides a historical review of the most significant contributions to the emergence of the 2012 phenomenon.
\end{abstract}

Keywords. 2012 phenomenon, astrology, Maya

\section{Introduction}

Assertions of ancient Maya prophecies associated with the end of the 13th baktun and its GMT-correlated date of December 21, 2012 have resulted in a bewildering plethora of publications, websites, documentaries, workshops, conferences, and self-help seminars with little basis in either archaeology or astronomy. Just as concerns about Y2K fueled massive investment in software development, underwriting the 'dotcom' bubble of the late 1990s and contributing to the emergence of the World Wide Web, the 2012 phenomenon (Sitler 2006) is creating a bubble in New Age metaphysics. According to popular mythology, the ancient Maya predicted that this date would be accompanied by either global catastrophe or a 'transformation of consciousness' that would usher in a long-awaited New Age, anticipated by mystics and Theosophists on the basis of the Book of Revelation and Medieval Arabic astrology. Predictions include 'earth changes', a global flood, a supervolcano, a dramatic magnetic or physical shift of the Earth's poles, the arrival of Planet X, visits from extraterrestrials, an increase in telepathy, and a shift in negative attitudes about the benefits of cannabis and metaphysical revelations (Joseph 2007; Stray 2009). The origins of the phenomenon can be traced to comments made by respected academic Mayanists and its promotion has included speculative statements by scholars, some of whom have doctoral degrees.

\section{Overview}

At present, there are over a thousand books in print that address the 2012 phenomenon. Three represent scholarly critiques (Aveni 2009; Van Stone 2010; Restall \& Solari 2011) and there are only two scholarly articles (Sitler 2006; Hanegraaff 2010). The meme 'tipped' (Gladwell 2000) in 2007. It was discussed in counterculture circles at the Burning Man festival, where in 2003 the central icon stood atop a Mesoamerican-style pyramid before its own apocalyptic incineration. However, its historical antecedents can be found in the millenarianism of Joachim de Fiore and its roots in the revival of astrology and the 'concordance of astronomy with history' by Bishop Pierre d'Ailly. The latter had a direct and profound effect on the thinking of Christopher Columbus, whose

1 A phrase coined in the early 20th century by psychic Edgar Cayce and associated with Atlantis. 
Libro de las Profecías sought to use sources from antiquity and ecclesiastical scholarship to prove that his prophesied discovery of 'most remote land' would precipitate the reconquest of Jerusalem, the Second Coming, and the end-times events described in the Book of Revelation. "Columbus turned to the writings of Pierre d'Ailly in order to improve his understanding of the connection established in Christian eschatology between the imminent last days of the world and a providential view of history. His aim was to locate his own enterprise within this scheme" (Columbus \& Rusconi 1997: 21). ${ }^{2}$ Columbus was compiling this "Book of Prophecies" on his fourth voyage in 1502, during which he encountered a trading canoe off the Bay Islands of Honduras and interviewed a local cacique on Guanaja. This first encounter between Europeans and the Maya world was the occasion on which the existence of the continental mass of Central America became understood and the episode in which 'Maia' first appears in European records (Academia de Geografía e Historia 1952). The Maya were associated with confirmation of eschatological mythology from this initial encounter, which was followed by the introduction of Western millenarianism first to the Antilles and Panama and subsequently to Maya converts in the Yucatan. From a Western perspective, there has always been 'New Age' thinking about the ancient Maya. ${ }^{3}$

The 2012 phenomenon is the result of speculative academic hypotheses, some discarded long ago and some not. Scholarship on the ancient Maya - academic and otherwise - has included many crackpots. Lord Kingsborough, who commissioned facsimiles of Mesoamerican codices and descriptions of Maya ruins in the 1830s, believed Mesoamericans were the Lost Tribes of Israel. Charles Brasseur de Bourbourg, discoverer of the Popol Vuh and Bishop Landa's Relación, found narratives of past destructions that led him to speculate about similarities between Maya culture and Plato's Atlantis, asserting direct connections with the lost continent. Waldeck illustrated Maya reliefs with Classical and Egyptian embellishments. Desiré Charnay suggested that the Toltecs were Aryans who had migrated to Mexico from the Himalayas. Augustus Le Plongeon, the first excavator of Chichén Itzá, identified the roots of Freemasonry through ancient Egypt and Atlantis to the Yucatan some 11,500 years ago. His work inspired Ignatius Donnelly $(1882 ; 1883)$ to trace not only the Maya but all civilizations to Atlantis and assign catastrophism a role in ancient history.

The persistence today of discarded theories about the Maya reveals a separate, esoteric tradition of scholarship that has accompanied academic Maya studies much as astrology has accompanied astronomy (Campion 2008). Its goals are metaphysical, spiritual, subjective, and distinctly not Western science. Esoteric Maya studies preserve archaic forms of knowledge that support New Age ideologies but do not withstand objective scrutiny. Specific assertions about 2012 derive from statements made by reputable scholars - the experts of their time - that were misinterpreted in unanticipated ways. These include a

2 Columbus made special note of a passage from Seneca's Medea, published for the first time in 1491: " 'During the last years of the world, the time will come in which the Ocean sea will loosen the bounds and a large landmass will appear; a new sailor like the one named Tiphys, who was Jason's guide, will discover a new world, and then Thule will no longer be the most remote land.' ... He wanted, moreover, to clinch the argument that these events were part of a larger eschatological perspective. Toward that end, in a margin of the letter to Ferdinand and Isabella in the manuscript of the Book of Prophecies, he wrote the same rubric that precedes the Latin lines of verse and placed a sign indicating that in the final version of the letter a paragraph, inspired by those verses, should be inserted before the one identifying premonitory signs of the final days of the world found in the Bible" (Columbus \& Rusconi 1997: 34).

${ }_{3}$ Columbus himself employed apocalyptic imagery associated with astronomy in his interaction with indigenous people, using the prediction of a lunar eclipse on February 29, 1504 to intimidate natives of Jamaica into provisioning his ships (Morison 1942: 653-654). 
chain of speculative inferences that runs from Ernst Förstemann to Sylvanus Morley to Michael Coe. Förstemann (1906) made reference to 'destruction of the world', 'apocalypse', and 'the end of the world' in his commentary on the last pages of the Dresden Codex. These were repeated by Morley (1915), who paraphrased the earlier scholar and added his own embellishments, such as references to a universal destruction of the world and a 'final all-engulfing cataclysm' in the form of a Great Flood. ${ }^{4}$ Morley repeated this in The Ancient Maya (1946) as he appropriated uncited details from Alfred Tozzer's (1941) translation of Landa. In so doing, he conflated pre- and post-Conquest stories, mentioning flood legends likely introduced by 16th century Christian missionaries, in turn influenced by speculation concerning a 'Second Great Flood' predicted for 1524 (Pankenier 2009). It is not at all clear that stories of 'universal' floods (past or future) have pre-Conquest Maya origins.

The basic workings of the Long Count calendar had been published by Goodman (1897), who also provided detailed tables of 1,897,000-day baktuns, which he asserted were conceived in a 73-unit 'grand era' that included the 53rd beginning on 13.0.0.0.0 4 Ajaw 8 Zotz (now correlated to April 1, 8239 BCE), the 54th beginning on 13.0.0.0.0 4 Ajaw 8 Cumku (August 11, 3114 BCE), and the 55th beginning on 13.0.0.0.0 4 Ajaw $3 \mathrm{~K}^{\prime}$ ank'in (December 21, 2012). However, this work drew the attention of only a small circle of scholars. Goodman made no calendrical associations with astronomical events or catastrophes.

Morley (1946) was the first to explain Maya cosmology to a general audience. Themes of Maya collapse and destruction from his book entered the counterculture with Beat writers in the 1950s. William Burroughs studied Aztec history and Maya writing at Mexico City College in 1950 and Allen Ginsberg made a long visit to Palenque in 1953. They were among a wave of tourism to Mexico after World War II that delivered a ready audience for Maya studies amidst a growing counterculture. Maud Makemson (1951), an astronomer, was the first to associate 13.0.0.0.0 4 Ajaw $3 \mathrm{~K}^{\prime}$ ank'in with end-of-the-world prophecies on the basis of the Book of Chilam Balam of Tizimin. However, her translation of the date and its meaning were flawed, resulting in a spurious Colonial-era prophecy that she correlated to 1752 . Her book introduced the date to a general audience amidst meaningless confusion.

Coe (1966) was the first to publish the correlation of a future Long Count date and associate it with 'Armageddon'. He correlated 13.0.0.0.0 4 Ajaw 3 K'ank'in to December $24,2011^{5}$ and introduced the concept of a Maya-predicted doomsday in a statement that has been made repeatedly in his popular text The Maya, now in its 8th edition (Coe 2011). Coe makes parallels between Mesoamerican and 'Oriental' religions, including similar concept of eras or kalpas. He also claims that the 'fifth world' which we inhabit, was to be 'destroyed by earthquakes'. This shift from the catastrophic flood of Förstemann and Morley to a fate predicted in the 1558 Aztec document La Leyenda de los Soles reflects beliefs about congruence in Aztec and Maya eschatology. The reference to Armageddon, written to stimulate his audience, undoubtedly reflected Cold War anxieties. Its repetition in subsequent editions of The Maya has fed the 2012 meme for four decades. ${ }^{6}$

4 The romantic imagery and excitement of the Maya's watery end may have come from Morley's youthful reading of Heart of the World, an adventure novel about the Maya by H. Rider Haggard (1895).

${ }^{5}$ Corrected in subsequent editions to December 23, 2012.

${ }^{6}$ It is important to note, however, that the principal dissemination of the doomsday date of December 24, 2011 was though use of Coe's book by writer Don Ringe for the script of "In Search of Ancient Astronauts", a 1973 TV documentary based on Erich von Däniken's Chariots of the Gods? (1969) that was seen by an audience of millions. 
2012 mythology came of age in the late 1960s as assertions about comparative mythology by MIT historian Giorgio de Santillana and his co-author Hertha von Dechend (De Santillana \& Von Dechend 1969) fueled speculation based on astrology and the I Ching. Though critically panned for its cherry-picking approach, ${ }^{7}$ Hamlet's Mill inspired myths about 2012. Its central premise is that world mythologies are based on observations of celestial events and that ancient knowledge of the precession of the equinoxes formed the backdrop to cosmological narratives. The authors suggest that initial knowledge of precession was ancient, occurring around 'Time Zero', a hypothetical date ca. 5000 BC during an undocumented and unexplained Golden Age, when major calendrical systems began. Hamlet's Mill influenced psychonauts Terence and Dennis McKenna, who found in it evidence for precession-linked cycles of 'novelty' that reached an 'eschaton' in 2012 they felt could be identified through a psychedelic-inspired analysis of the mathematics of the I Ching (McKenna \& McKenna 1975; Hanegraaff 2010). John Major Jenkins (1998; 2009), who drew direct inspiration from the McKennas, saw precession in the 5126-year Great Cycle of the Maya calendar, asserting that knowledge of precession was the basis for the Long Count and claiming the Maya specifically picked the 2012 winter solstice to celebrate a culmination of grand, 26,000-year-long precessional cycles.

If some assertions about 2012 sound as if they were imagined by people on drugs, it is because they were. The early 1970s were a heady time for speculation about Mesoamerican shamanism, cosmology, and metaphysics. Carlos Castaneda's books - not yet revealed as fraud - were earning him millions. They fostered interest in shamanism and psychedelics as paths to self-realization and had an effect on Mesoamerican studies. Furst (1972) included an essay by Castaneda's advisor Weston La Barre. Although a speculative article by Dobkin de Rios (1974) about Maya hallucinogen use fell flat among Mayanists, it inspired other speculative literature. At the same time, Furst (1975) offered a revised definition of Mesoamerican shamanism, one that gave a central role to hallucinogens and the concept of transformation (especially therianthropic). Castaneda influenced Furst's thinking - and vice-versa (De Mille 1976; Fikes 1993) — and this legacy has remained a part of both Maya studies and the 2012 phenomenon.

The year 1975 saw the publication of several influential books relevant to 2012. These were a product of the times. A zeitgeist that had included hyped anticipation of Comet Kohoutek in 1973 cast renewed attention on the heavens, including predictions of disaster. A popular TV documentary claimed the Mayas had been visited by extraterrestrials. Richard Nixon's 1974 resignation and the U.S. withdrawal from Vietnam undermined confidence in central authority, making alternatives seem credible and attractive. Poet Tony Shearer (1975) claimed that Maya prophecy predicted the end of the world on August 16, 1987, a date subsequently adopted by art historian José Argüelles for the Harmonic Convergence, a counterculture astrological event. Argüelles, who has a Ph.D. in Art History and Aesthetics from the University of Chicago, had been a heavy user of psychedelics, a founder of Earth Day in 1970, and was a student of astrologer Dane Rudhyar (1975). His was one of the first books to identify 2012 (not 2011) as a significant date for the Maya (Argüelles 1975), ${ }^{8}$ implying it would bring spiritual transformation. Frank Waters' book (1975), the result of a Rockefeller Foundation grant to study in Mexico in 1970-71, revisited the myth of a white, bearded Quetzalcoatl, the lost continent of Atlantis, and interpreted an astrological chart for December 24, 2011 (a date taken

7 Reviewer Cecelia Payne-Gaposchkin of the Smithsonian Astrophysical Observatory put it in the same category as Donnelly's Ragnarok and Velikovsky's Worlds in Collision.

8 This seems likely to have been a rounding of Coe's initial published date of December 24, 2011 rather than a direct calculation. The year was specified, but not the day. 
from Coe). The McKennas' book (1975) included discussion of a computer program derived from the I Ching that identified 2012 as the conclusion of a 4300-year cycle. Their work was influenced as much by the transformative power of mushrooms and other potent hallucinogens as the abovementioned Hamlet's Mill.

Argüelles' most influential book (1987) appeared in advance of the Harmonic Convergence. In it, he suggested that that ancient Maya had obtained knowledge of the galaxy from extraterrestrial beings and that on December 21, 2012 the Earth would come in contact with a beam of energy emanating from the center of the Milky Way that would usher in a time of metaphysical transformation and spiritual peace. Among other things, he predicted a visit from 'galactic ambassadors' in 1992-93. They have not yet arrived, though von Däniken (2010) asserts they are coming in 2012.

The books by Argüelles, Waters, and the McKennas were largely ignored by academics. Although Argüelles' book had been intended as a scholarly contribution, it was panned by critics. The McKennas' book attracted slight attention in the counterculture but soon went out of print. Waters' book, despite its prestigious funding, was also dismissed. However, all of these were subsequently revived and reissued in the 1990s, due in part to word-of-mouth popularity in counterculture lectures during the 1980s, a revival of psychedelics in the rave subculture in the 1990s, and especially the growth of cyberculture. The correlation of December 21, 2012 with 13.0.0.0.0 was first published in an appendix to the 4th edition of Morley's The Ancient Maya (1983). All of these books came back into print and are well-known among 2012 aficionados today.

The 2012 phenomenon today results from a merging of influence from the psychedelic subculture with ideas that emerged from the 'Texas School' of Maya studies that thrived around epigrapher Linda Schele at the University of Texas-Austin beginning in the late 1970s. Schele encouraged her students to read widely in the areas of comparative religion, with a special emphasis on shamanism. Mircea Eliade's work (1959; 1964), which emphasized a desire to return to primordial, archaic belief systems of the distant past, was particularly influential. He was an expert on yoga who used comparative analysis to find parallels between Eastern and Western thought. A special focus on 'shamans', vision quests, and complex symbol systems accompanied real breakthroughs in the decipherment of Maya writing. The work of Schele, her colleagues, and her students was highly collaborative, bringing together linguists, art historians, archaeologists, and ethnographers for a heady period of exciting discoveries.

A second wave of 'scholarly complicity' that fostered further speculation on ancient Maya cosmology led directly to current 2012 mythology. Linda Schele and David Freidel (Schele \& Freidel 1990; Freidel et al. 1993) asserted that ancient Maya rulers were shamans whose principal acts included dramatic performances in the context of celestial phenomena. In the model these present, the Milky Way is the World Tree, an axis mundi that represents the middle of the cosmos and connects a three-layered universe within which shamans travel. They also asserted that Maya cosmology is meaningful in contemporary society. This has been adopted in 2012-themed metaphysical literature.

Jenkins (1998; 2009), an active proponent of 2012 mythology, was directly inspired by a combination of themes in professional astrology, Hamlet's Mill and work by Waters, Argüelles, the McKennas, Schele and Freidel, and their associates. His work has evolved from a concentration on astrology to an imaginative reading of iconography at the site of Izapa, where he asserts the Long Count was created. Jenkins suggests the creators of the Long Count calendar were able to pinpoint a winter solstice and a 'galactic alignment' of the sun with the center of the Milky Way thousands of years in the future. Archaeoastronomers remain unconvinced. 
Many of the principal promoters of the 2012 phenomenon, including Jenkins, claim great insight from experiences using psychedelic substances. Jenkins (2009) attributes his insights into 2012 to the use of mushrooms and especially LSD in a sensory deprivation tank. Stray (2009), also an online chronicler of the 2012 phenomenon, attributes his initial interest to the work of the McKennas, especially visionary insights that resulted from psychedelic journeys. Daniel Pinchbeck (2006), another voice in promoting 2012 as a metaphysical event, was identified by Rolling Stone magazine as the leader of the 'new psychedelic elite'. His first book detailed visionary experiences on iboga, ayahuasca, and DMT (dimethytryptamine), the last during a conference on psychedelics at Palenque (Pinchbeck 2002). Inspired, he channeled the deity Quetzalcoatl and weaves crop circles, alien abductions, psi phenomena, and Hancock's theories about a 'lost civilization' into 2012 lore.

Other voices promoting 2012 as a metaphysical watershed include several authors with doctoral degrees. Carl Johan Calleman (2004; 2009), a pharmacologist with a Ph.D. in Physical Biology from Washington University, has created a new cosmology based on the Maya calendar. Semir Osmanagich (2005), with a Ph.D. in Anthropology from the University of Sarajevo, has used it to promote interest in the spurious Bosnian 'pyramids'. Robert Sitler (2010), who has a Ph.D. in Hispanic Literature from the University of Texas, also writes from a New Age perspective, invoking psychedelic-induced visionary experiences and personal growth.

Should we discount hypotheses about 2012 because they resulted from psychedelic experiences or because their proponents have New Age leanings? Of course not. Psychedelics have played a significant role in contemporary culture, beginning with the Beatles. They have had an unmistakable impact, from fantasy and science fiction to computer graphics (especially in the film industry) and computer gaming. Hallucinogens and fascination with the cosmos have gone hand in hand since the first person entered an altered state of consciousness and looked up into a night sky filled with stars. There's a reason why drug use and 'spaciness' go together. Psychedelics generate a sense of other worlds, which is why psychedelic users are drawn to thoughts about other dimensions, alternative universes, and extraterrestrial intelligence. The same is true for metaphysical discourse. Good science doesn't care where good hypotheses originate, even if they come from psychedelic epiphanies. The bottom line is that we can discount unsupported hypotheses about 2012 exactly the same way we discount those about Atlantis, Lemuria, ancient astronauts, pyramid power, astral projection, and ESP: Occam's Razor and the absence of persuasive scientific evidence.

\section{Conclusion}

The 2012 phenomenon is an astrological and cultural event, not an astronomical one. Apart from the winter solstice and the proximity of the sun to the galactic center of the Milky Way (something invisible to the naked eye that has been occurring every December for over a decade), there is little special that happens on December 21, 2012. However, assertions that the ancient Maya associated this date with unique astronomical events are unconvincing. The hullaballoo is a projection of present-day astrological concerns on an ancient culture by earnest believers in New Age lore. It is primarily a manifestation of contemporary pop culture.

The 2012 phenomenon is both amusing and disconcerting. The latter, because it casts suspicion on scholars. We have scientific facts about past catastrophes such as the Chicxulub meteorite of 65 mya. We even have some good ideas about present ones, such as oil spills and global warming, even if our plans for avoiding these in the future remain 
murky. Science has cast doubt and even ridicule on metaphysics and the supernatural. Our understanding of consciousness, neurophysiology, and cognition remains inadequate for explaining revelations - including those under the influence of LSD or DMT - that seem 'real'. The public's perception of scholars has been colored by a string of individuals who have identified themselves as credentialed scholars while engaging in unfounded and even pseudoscientific speculation.

Nicholas Campion's (2008; 2009) scholarship on the history of astrology helps clarify what it is that makes astrology seem legitimate, but 2012 presents other related mythological themes that also merit consideration, among them what it is that makes the past as presented by science appear 'real' or not. As with Creationism, there is a rejection of the 'official' narratives about the ancient Maya and with them the rejection of academic authority. Just as many astronomers know nothing and care less about the power of astrology, archaeologists have similar attitudes regarding mythology about lost 'archaic knowledge' and 'ancient wisdom' that has been generated from a psychedelic and/or metaphysical perspective.

The 2012 phenomenon brings a fascinating intersection of astronomy and culture. At the very least, it has made a huge audience aware of Maya calendrics and the winter solstice. However, its study brings to mind a vignette from the journals of Eliade (1990). During his participation at a conference on this history of religion in Switzerland he wrote: "22 August [1950] ... Jung told [Henry] Corbin that he is grief-stricken over the real existence of 'flying saucers'. Always he believed in the symbolic significance of the circle and the circular; now that 'the circle' seems actually to be 'realized', it no longer interests him. It seemed infinitely more real to him in dreams and myths." As with flying saucers for Jung, the 2012 phenomenon may be far more interesting as a window into our contemporary culture - especially how our scholarship is consumed in ways we intend or not - than for anything its reality reveals about the ancient Maya.

\section{References}

Academia de Historia y Geografía 1952, Colección de Documentos para la Historia de Costa Rica Relativos al Cuarto y Último Viaje de Cristóbal Colón, Imprenta y Librería Atenea, San José.

Argüelles, J. 1975, The Transformative Vision: Reflections on the Nature and History of Human Expression, Shambhala, New York.

Argüelles, J. 1987, The Mayan Factor: Path Beyond Technology, Bear \& Co., Santa Fe NM.

Aveni, A. F. 2009, The End of Time: the Maya Mystery of 2012, University Press of Colorado, Boulder.

Calleman, C. J. 2004, The Mayan Calendar and the Transformation of Consciousness, Bear \& Co., Rochester VT.

Calleman, C. J. 2009, The Purposeful Universe: How Quantum Theory and Mayan Cosmology Explain the Origin and Evolution of Life, Bear \& Co., Rochester VT.

Campion, N. 2008, The Dawn of Astrology: a Cultural History of Western Astrology, Continuum, London \& New York.

Campion, N. 2009, History of Western Astrology. Volume II, the Medieval and Modern Worlds, Continuum, New York.

Coe, M. D. 1966, The Maya (1st edn), Praeger, New York.

Coe, M. D. 2011, The Maya (8th edn), Thames \& Hudson, New York.

Columbus, C. \& Rusconi, R. 1997, The Book of Prophecies edited by Christopher Columbus, Repertorium Columbianum 3, University of California Press, Berkeley.

De Mille, R. 1976, Castaneda's Journey: the Power and the Allegory, Capra Press, Santa Barbara. 
De Santillana, G. \& Von Dechend, H. 1969, Hamlet's Mill: an Essay on Myth and the Frame of Time, Gambit, Boston.

Dobkin de Rios, M. 1974, The influence of psychotropic flora and fauna on Maya religion. Current Anthropology 16(2), 147-164.

Donnelly, I. 1882, Atlantis: the Antediluvian World, Harper, New York.

Donnelly, I. 1883, Ragnarok: the Age of Fire and Gravel, D. Appleton \& Co., New York.

Eliade, M. 1959, Cosmos and History: the Myth of the Eternal Return, Harper, New York.

Eliade, M. 1964, Shamanism: Archaic Techniques of Ecstasy, Routledge \& Kegan Paul, London.

Eliade, M. 1990, Journal I, 1945-1955, University of Chicago Press, Chicago.

Fikes, J. 1993, Carlos Castaneda: Academic Opportunism and the Psychedelic Sixties, Millennia Press, Victoria.

Förstemann, E. W. 1906, Commentary on the Maya manuscripts in the Royal Public Library of Dresden, Peabody Museum, Cambridge MA.

Freidel, D., Schele, L., \& Parker, J. 1993, Maya Cosmos-Three Thousand Years on the Shaman's Path, Morrow \& Co., New York.

Furst, P. T. 1972, Flesh of the Gods: the Ritual Use of Hallucinogens, Praeger, New York.

Furst, P. T. 1975, Shamanistic survivals in Mesoamerican religion. In Actas del XLI Congreso Internacional de Americanistas 41, Museo Nacional de Antropologa, Mexico City, pp. 149157.

Gladwell, M. 2000, The Tipping Point: How Little Things Can Make a Big Difference, Little, Brown \& Co., Boston.

Goodman, J. T. 1897, Appendix: the Archaic Maya inscriptions. In A. P. Maudslay (ed.), Biologia Centrali-Americana, Taylor \& Francis, London.

Haggard, H. R. 1895, Heart of the World, Longmans, Green \& Co., New York.

Hanegraaff, W. J. 2010, 'And End History. And Go to the Stars': Terence McKenna and 2012. In C. M. Cusack \& C. Hartney (eds), Religion and Retributive Logic: Essays in Honour of Professor Garry W. Trompf, Brill, Boston, pp. 291-312.

Jenkins, J. M. 1998, Maya Cosmogenesis 2012: the True Meaning of the Maya Calendar EndDate, Bear \& Co., Santa Fe NM.

Jenkins, J. M. 2009, The 2012 Story: the Myths, Fallacies, and Truth Behind the Most Intriguing Date in History, Jeremy P. Tarcher/Penguin, New York.

Joseph, L. E. 2007, Apocalypse 2012: a Scientific Investigation into Civilization's End, Morgan Road Books, New York.

McKenna, D. J. \& McKenna, T. K. 1975, The Invisible Landscape: Mind, Hallucinogens, and the I Ching, Seabury Press, New York.

Makemson, M. W. 1951, The Book of the Jaguar Priest, Schuman, New York.

Morison, S. E. 1942, Admiral of the Ocean Sea: a Life of Christopher Columbus, Little, Brown \& Co., Boston.

Morley, S. G. 1915, An Introduction to the Study of the Maya Hieroglyphs, Bureau of American Ethnology Bulletin 57, Smithsonian Institution, Washington DC.

Morley, S. G. 1946, The Ancient Maya, Stanford University Press, Palo Alto.

Morley, S. G. 1983, The Ancient Maya (4th edn), Stanford University Press, Stanford.

Osmanagich, S. 2005, The World of the Maya, Euphrates, Piscataway NJ.

Pankenier, D. W. 2009, The planetary portent of 1524 in China and Europe. Journal of World History 20(3), 339-375.

Pinchbeck, D. 2002, Breaking Open the Head: a Psychedelic Journey into the Heart of Contemporary Shamanism, Broadway Books, New York.

Pinchbeck, D. 2006, 2012: The Return of Quetzalcoatl, Jeremy P. Tacher/Penguin, New York.

Restall, M. \& Solari, A. 2011, 2012 and the End of the World: the Western Roots of the Maya Apocalypse, Rowman \& Littlefield, Lanham MD.

Rudhyar, D. 1975, The Sun is Also a Star: the Galactic Dimension of Astrology, Dutton, New York.

Schele, L. \& Freidel, D. A. 1990, A Forest of Kings: the Untold Story of the Ancient Maya, Morrow, New York.

Shearer, T. 1975, Beneath the Moon and Under the Sun: a Poetic Re-Appraisal of the Sacred Calendar and the Prophecies of Ancient Mexico, Sun Publishing Co., Albuquerque NM. 
Sitler, R. 2006, The 2012 phenomenon: New Age appropriation of an ancient Maya calendar. Novo Religio 9(3), 24-38.

Sitler, R. 2010, The Living Maya: Ancient Wisdom in the Era of 2012, North Atlantic Books, Berkeley.

Stray, G. 2009, Beyond 2012: Catastrophe or Awakening? A Complete Guide to End-of-Time Predictions, Bear \& Company, Rochester VT.

Tozzer, A. M. 1941, Landa's Relación de las Cosas de Yucatan, a Translation, Papers of the Peabody Museum of American Archaeology and Ethnology 18, Peabody Museum, Cambridge MA.

Van Stone, M. 2010, 2012: Science and Prophecy of the Ancient Maya, Tlacaélel Press, Imperial Beach CA.

Von Däniken, E. 1969, Chariots of the Gods? Memories of the Future-Unsolved Mysteries of the Past, G. P. Putnam's Sons, New York.

Von Däniken, E. 2010, Twilight of the Gods: the Mayan Calendar and the Return of the Extraterrestrials, New Page Books, Pompton Plains NJ.

Waters, F. 1975, Mexico Mystique: the Coming Sixth World of Consciousness, Sage Books, Chicago. 